\section{What's so good about participation? Politics, ethics and love in Learning Together} May-August 2020: I-10 (C) The Author(s) 2020 Article reuse guidelines: sagepub.com/journals-permissions DOI: $10.1177 / 2059799120927339$ journals.sagepub.com/home/mio

(SSAGE

\author{
Ruth Armstrong and Amy Ludlow
}

\begin{abstract}
This article tells the story of our movement towards using participatory approaches in an action research project aiming to understand the experiences and impacts of belonging to learning communities that span prison and university walls. We draw on our experiences over the past 5 years of building learning communities involving students from higher education and criminal justice organisations and describe some of our attempts to provide creative opportunities for participation and voice within research. We highlight some of the benefits that we have seen through adopting these approaches, as well as some of the discomforts that we, and our students, have experienced. We use these examples to question for whom we think participation 'works', whether participation is always good, or whether it can, rather, sometimes cause harm, and the extent to which participation addresses some of the ethical concerns levelled at more traditional approaches to social science research, including matters of power, purpose, positioning and personhood. Using the work of Cantillon and Lynch as an orienting framework, in the conclusions we return to their arguments to suggest that the benefits of participatory action research might not be in alleviating these ethical concerns, but rather in establishing affective links between people occupying different roles within research, thus imbuing the process with love. This has the potential to transform all of the actors, and the research itself.
\end{abstract}

\title{
Keywords
}

Participation action research, ethical sensibilities, transformative learning, creative research practices, prison and university partnerships

Sometimes, you read a piece of work that strikes you as so good, so true, so provocative, so wrong or so well written, that you just have to write about it. Recently, this happened to us. We founded and direct 'Learning Together', ${ }^{1}$ an action research initiative through which we build communities of learning involving students from universities and students under criminal justice supervision. ${ }^{2}$ We collaborate with colleagues at over 25 universities and criminal justice institutions in England and beyond, to build and evaluate communities of learning that span prison and university walls. In one of our prison-based reading groups, a student introduced us to a short piece entitled 'Fuck you and fuck your fucking thesis: why I will not participate in trans studies'. ${ }^{3}$ We read it aloud, together with our students, and variously gasped, felt shame and laughed. Anne's words sat 'heavy' on us, describing challenges of politics and ethics that felt intimately familiar to us, having grappled for the past 5 years with what co-production might - and might not - mean for evaluating Learning Together.
This article contains some of our reflections on those challenges, provoked anew by Anne's experiences. We begin with a more detailed account of Anne's article, describing problems of power, purpose, positioning and personhood in research methods, and introducing participatory action research (PAR) as one methodological response to these concerns. In the second section of this article, we describe Learning Together and our journey into PAR, before reflecting on our experiences, both of PAR's potential (section 'The potential of PAR') and difficulties (section 'Disruptions, difficulties and discomforts of PAR - Sarah, Angela, Haydn and Patrick's experiences'). We conclude by reference to Cantillon and Lynch's (2017) work on 'affective justice'. ${ }^{4}$

University of Cambridge, Cambridge, UK

Corresponding author:

Ruth Armstrong, University of Cambridge, St John's Street, Cambridge, CB2 ITP, UK.

Email: ra299@cam.ac.uk 
They argue that parity of participation in social and political life is unlikely to achieve its goals 'without recognizing the primacy of affective relations in the framing, and misframing, of social justice' (Cantillon and Lynch, 2017: 173). We draw on their analysis to consider what it might mean to recognise and build towards 'labours of love' in how we undertake research and what we do with our findings.

\section{Problems of power, purpose, positioning and personhood in research methods}

Dear Mr. or Ms. Grad Student, I am sorry to report that I will not participate in your study as a data point. I don't understand what you're trying to accomplish. I don't trust you. I don't like you. I don't care if you succeed. In fact, I kind of think you suck. Here's why:

This is the opening paragraph of the letter written by Anne to an unidentified graduate student. The piece is an account of Anne's discomforts with research on 'trans' people and being researched as a trans person. Anne rails about what it feels like to be used - 'interviewed, sampled, tested, cross-referenced, experimented upon, medicated, shocked, examined and dissected' - more for an individual researcher's career gain than impact that makes a difference to the trans community. She describes how it feels to be classified within a 'marginalised group' and pathologised as a site of study within such a group - 'you've looked at our chromosomes, our families, our blood levels, our ring fingers, our mothers' medicine cabinets, and our genitalia (over and over again with the genitalia ...)' - but never listened to - 'You've listened to our ears. You've listened to our fucking ears! But you've never listed to our voices ...' Anne then moves on to identify some of what she sees as the real needs of trans people, which she argues do not seem to be seen or of interest to 'Mr. or Ms. Big-Shot Researcher Who Wants To Do Something Good For the World'. 'So what do people like me need?', Anne asks. 'Not counselling. Not new labels on condoms. Not more doctoral candidates palpating our business. Transwomen need, more or less in order: decriminalisation, housing, education and employment'. 'You want to actually do something as good as you say you want to do, [then] drop out, abrogate your loans, and become a social worker'.

Anne is identifying power imbalances in research, and the consequences of feeling objectified and powerless ('like a data point'). She is expressing frustration with the purpose of research, which she describes as a process directed more towards achieving 'impact' in narrow academic terms (making individual researchers feel good about themselves and pushing them up the career ladder), rather than research that has tangible benefits for those it involves and affects, in terms of things they care about. But Anne goes further, describing not only how research may not be doing good, but also how it may cause harm. Anne identifies the researcher with 'the people who run the world around us', and questions whether researchers have ever considered studying themselves, suggesting that they (the researchers) may be part of 'the problem' because of how and with whom they frame and explore research questions. But Anne is not eschewing the value of research entirely. In her final paragraph, she describes a need for 'data, ideas, plans and strategies', but argues that 'we need to see them coming from people like us, people who don't, right now, seem to make it into your little position of power'. Research too often positions and understands Anne and others in ways that are pigeonholing, objectifying and stigmatising, reinforcing binaries established in social dynamics that situate the socially marginalised and privileged in different roles on the 'social change maker' spectrum. Anne's response is to suggest she'd rather be left alone.

Anne's provocations about power, purpose, positioning and personhood in research methods are of long-standing concern within parts of the academic community. Growing interest in methodological reflexivity, especially perhaps in qualitative scholarship, has given rise to broad and varied literatures on paradigmatic and fieldwork standpoint difference (e.g. Carlen and Ayres França, 2017; hooks, 1990; Miller, 2012; Ramazanoglu and Holland, 2002; Tyler, 2008) and explorations of 'vulnerability', privilege and experience on the part of both the researcher and the researched (e.g. Armstrong et al., 2014; Behar, 2014 (1996); Beyens et al., 2013; Gelsthorpe, 2007; Holland, 2007; Sharpe, 2016). Scholars have explored the politics of method - how politics shape the questions we ask and how we ask them, the relationships between social science, values and ethics, and what it means to 'do justice' to research findings and 'have impact' in and with the world (e.g. Bosworth and Hoyle, 2011; Flyvbjerg, 2001; Lincoln and Denzin, 2003; Sayer, 2011).

PAR is one example of a methodological approach that grapples explicitly with some of the critiques of power, purpose, positioning and personhood that run through Anne's article and that animate some of the scholarship briefly described above. In her short book on PAR, Alice McIntyre describes how the method aims to build alliances between researchers and participants through planning, implementing and disseminating research together, co-constructing knowledge and working towards shared ambitions for individual, collective and/or social change (McIntyre, 2008). Co-producing research projects' purposes and processes is intended to disrupt more traditional research power dynamics that pigeonhole, marginalise or privilege particular perspectives. PAR, McIntyre argues, recognises the personhood of participants through their becoming the 'primary actors' of the research process. McIntyre (2008) credits PAR with enabling her to play a role in effecting change, self-identifying as a scholar who is interested in staying 'engaged in life, scholarship, research, reaching and the pursuit of justice and fair play' (dedication). Michelle Fine (2016) goes further, 
describing PAR as a political act, urgently needed to produce 'ideological contestations' that can 'investigate the claims of dominant narratives, lift up counter stories, and dive into the knotty relation between the two as well as generate images of radical possibilities'. For Fine (2017), this encompasses contesting the ideologies dominant in research institutions as well as those that pertain to research topics. Research methodologies, she argues, influence not only the individual personhood of those leading and taking part, but also the culture of the institutions inhabited by the different players in the research process.

\section{Our journey into PAR}

Empirical research is a process of 'continuing dialogue' between epistemological and theoretical starting points, methodological approaches and research findings (Bottoms, 2008). Designed as an action research project, Learning Together brought together three strands of existing scholarship - transformative education, desistance from crime and intergroup contact theory - and promised to 'advance theoretical understandings of the transformative potential of prison education and its contribution to early stage desistance through observing, operationalising and measuring the interpersonal dynamics of individual movements towards desistance in prison'. ${ }^{5}$

Informed by research that demonstrates the potential of co-production for enhancing the transformative outcomes of education (Freire, 1973; Mezirow, 2000) and for supporting movements away from crime (e.g. Weaver, 2015), the pedagogy of Learning Together is grounded in inclusive and participatory community building. Learning Together is designed to take account of the elements intergroup contact theory suggests are important to creating environments in which stigma and prejudice can reduce. Such environments equalise the status of those present, require intergroup cooperation, forge common goals and pay attention to overarching institutional and social narratives (Allport, 1954). We were not blindly forging our way into prisons to deliver contact higher education courses believing that action in and of itself is good, or that action of our particular kind would inevitably have good consequences. We were mindful of Wikström and Treiber's (2007) warnings about 'doing without knowing', but also felt responsible as academics to use and test knowledge for social good and so committed to avoiding the inertia of 'knowing without doing' (Armstrong and Maruna, 2016) and the privilege of sitting on the sidelines and criticising. We had a theoretical framework for our action that we intended to guide our practice. We were prepared for a process of 'adaptive theory' (Bottoms, 2008) how our empirical realities would shape our theory. What we didn't count on from the start, was how our theory and practice would shape our methods, and how our methods would, in turn, reshape our theory, prompting us to redefine 'the problem' and rethink our theoretical lenses into how we might understand and address it.

\section{Our original research design}

In line with other prison scholars (e.g. Liebling and Arnold, 2004; Wooldredge and Smith, 2018), we viewed ethnographically led measurement as one way to develop measurement tools (survey instruments) that can capture complex human social phenomenon, and generate measures that are recognised by participants who often feel marginalised and unrecognised (Liebling, 2015). We understood this as a way to 'find the right language' with which to express the relevant preexisting theoretically informed scales that we proposed to adapt, measuring problems faced in desistance (used in the Sheffield Desistance Study by Bottoms and Shapland, 2011), the development of civic virtues (Farrall and Calverley, 2006), perceptions of stigma (LeBel et al., 2008) and 'normalisation' (Hirschfield and Piquero, 2010). The British Academy proposal envisaged the delivery of a course that brought together students from the University of Cambridge and students who were currently resident in prison and sought to put into practice key findings from the literatures described above and the evaluation of the participants' experiences. The proposal divided the research aspect of this work into three stages: (1) a pilot to test the pre-existing scales and adapt them in light of ethnographic engagement in one site; (2) an intermediate phase to implement the adapted scales across two sites, including a control group of students who had applied to take part but were placed on a waiting list; and (3) a final phase to repeat administration of a further refined measurement tool across the same two sites, with the aim of getting close to 100 participants overall. The results of the survey tools we produced were to be interpreted in light of field notes, individual interviews and data from focus groups. The proposal was intended to be methodologically rigorous - robust enough to get funding and the support of colleagues, tightly theoretically and methodologically framed to increase the chances of publication in high-ranking journals, and a solid basis for further longitudinal study. The action components of the initiative were conceived in methodological terms as developing 'buy in' and contextual sensitivity for the 'measurement tool'.

In November 2014, we recruited students from the University of Cambridge criminology department and from HMP Grendon and, in January 2015, we began teaching the first Learning Together 'introduction to criminology' course. We asked the students if they wanted to take part in the research. Some declined, but most students said they were happy to participate, so we gave them our 'pre' measures questionnaire to fill out ahead of the first week. We had thought hard about pedagogy and about co-production in light of our theoretical framework. We drafted a note for our lecturers asking them to define all of their terms, to deliver their 30-minute lecture dialogically, and we built in work in small groups, with different activities for different learning styles. In the first session, we worked with the whole group of students to identify and understand everyone's aspirations and expectations for the course and to tease out what that meant for each of us in terms of our participation and how we 


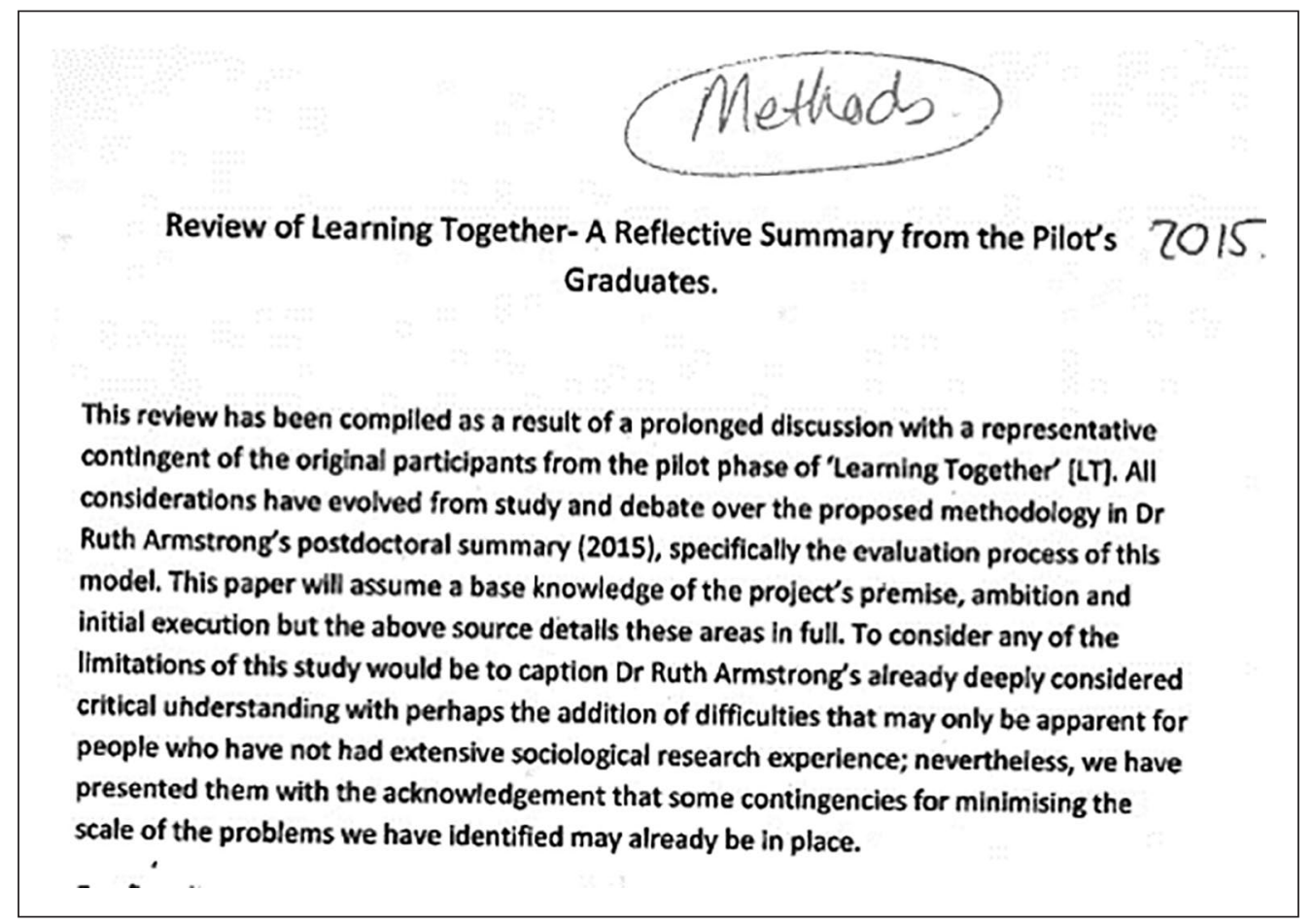

Figure I. Photograph of the first page of the students' critique of our methods.

would achieve these aspirations and expectations while respecting the security requirements and rules of the prison and the university. We did not have separate security briefings for different groups of students, conscious of how this would disrupt parity in the classroom. We built in a session in the third week to reflect on the students' aspirations and expectations and to think about aspects of the course that needed to change if we were to meet them. We encouraged students to come up with their own ideas about what needed to change and we worked together to implement them. The course started tentatively, but together, we built something that felt meaningful - for us as well as for the students.

And then it ended. We distributed the post-measure questionnaires and scheduled one to one qualitative interviews with each student. Two things had changed: the first was that everyone now wanted to take part in the research; and the second was that, through the process of co-producing the course, our students had become accustomed to critical engagement. They were no longer happy to be the receptacles of preordained wisdom imposed from on high. We had experienced the power of a Freirian approach to individual, institutional and social transformation through learning (Armstrong and Ludlow, 2016). Our students were no longer happy to "participate' in research, they wanted to be collaborated with. They told us that our methods were out of sync with our practice, and made them feel objectified. We didn't lack 'buy-in' - we had that in spades - but they told us the 'buy-in' didn't make our methods any less objectifying. We listened to their discomforts and, in response, we sent them our original research proposal and asked them what they would do differently. They organised themselves into a focus group and provided us with a five-page critique of our methods which described how they felt we were asking the wrong questions, about the wrong things, in the wrong ways (Figure 1).

\section{Letting go and getting back together}

Our students' five-page critique was the beginning of co-producing not only the learning in our classrooms, but also our research into the experiences and outcomes of participating in a Learning Together course. Most pressing for our students (and for us) was the question 'what next?'; what next in terms of action and evaluation, but also what next in terms of 'us' because, through Learning Together, we had become an 'us'.

The following year, we worked collaboratively on our evaluation together with our new students and our previous students who became trained learning mentors to support the new students. We began by listening. We listened through the qualitative interviews at the end of the first year, and we realised that certain voices and personalities are more suited to narrative methodologies. We listened through our participant observation throughout the first course, sensing the centrality of social and spatial context and interpersonal interaction within processes of transformation, while noting that context and interaction often go 'uncounted' in research and are difficult to measure. We put some of what we heard into practice, co-creating the second course, and in the process changing the syllabus and some aspects of the delivery, and scrapping our original research methods in favour of something more participatory, for which we had no clear road map. 
We started by talking with students about wanting to work with them throughout the course to understand their experiences and to think together about what was happening, what was most important to understand about what was happening, how we might best measure those things and to what ends. We asked students about ways they might like to work together not just in their learning, but also to evaluate Learning Together. We ran slam poetry workshops with Joelle Taylor, ${ }^{6}$ song writing workshops with Vox Liminis, ${ }^{7}$ we made a short film together with our students under the guidance of Kip Loades, ${ }^{8}$ ran focus groups and shared our own experiences of Learning Together and continued to do semi-structured qualitative interviews with individual students at the end of each course. We anonymised all of the data, and then gathered as a community to explore the data. It was an enlivening - and sometimes nerve wrecking - process. We didn't set out at this point to conduct PAR, cognisant of the literature and contours of the process. We just decided to listen and collaborate and see what grew from this. It was in trying to understand what we were doing that we found it describe in literature on PAR.

Sometimes we were caricatured within the university as chaotic or eccentric - often gathering large groups of students in reception to bus them to prison for class, or shepherding budding filmmakers on day release from prison around the library and offices to film our university environment and willing colleagues. We upturned some of the experiences of 'researcher' and 'researched' and found that having people observe our own working environment - as we had done for so many years in criminal justice organisations - was sometimes a little bit disruptive for professional life! This was a period characterised by incessant working hours, some mayhem and plenty of uncertainty, and yet it is a period that felt for us, as colleagues, uniquely collaborative and life giving. In the dialogue between theory and methods, our methods started to talk back and led us into new and broader theoretical frameworks: from straightforwardly positive trajectories of transformative education into more emotionally diverse experiences of learning and transformation (e.g. Dirkx et al., 2006; Maiese, 2017; Weare, 2003) from narrow understandings of desistance as movements away from crime to broader literatures on porous community building where people meet at edges and form entwined senses of interdependence (e.g. Bauman, 2013 [2001]; Seligman, 2008; Sennett, 2012) ${ }^{9}$ from psychological understandings of intergroup contact into geographical and political considerations of how to conceive and construct meaningful interactions that don't let 'the thorny matters of inequality slip out of the debate' (e.g. Harris, 2017; Nussbaum, 2013; Valentine, 2008).

\section{The potential of PAR}

We began this article with frustrated reflections from Anne about research that misunderstood, misappropriated and compounded her 'marginalisation'. Drawing on Anne's experiences, we described problems of power, purpose, positioning and personhood in research methods. Our experiences of PAR suggest to us that it can go some way to mitigating some of these concerns, and in this section, we share some of those reflections, counterbalanced in the penultimate section of this chapter, which follows, with reflections about how PAR may displace rather than entirely diminish Anne's concerns.

The first benefit of PAR we experienced was the way in which a participatory approach repositioned vulnerability and power and in doing so, reframed the purpose of the research. Through being willing to lead with vulnerability, with curiosity about what the important questions might be, and how we might work together to enquire into them, we became an 'us'. In place of artificial and pigeonholing distinctions between 'marginalised' and 'privileged' students and all-knowing objective 'researcher' versus uninformed subjective 'researched', we committed to pursuing a research agenda that was about understanding what was happening to 'us' as we went through a process of co-produced learning. To use Anne's language, with this approach we did not cease to be 'data points', but we reframed the terms of our inquiry and our parts in it together, and each of us became an important part of understanding the whole. We had different sites of expertise - but our differences were not understood in binary terms along lines of 'power holder' and 'marginalised participant'. Together, we all moved further towards asking questions than finding answers.

As the power balance shifted through participation, so did the purpose of the research. While we were always interested in the experiences of all of our students, our original lens of analysis was explicitly to understand processes of desistance - how people move away from crime. However broad and inclusive our original proposed sample, the aim was to describe how 'they' moved towards 'us' - how people who had been convicted of criminal offences moved away from these behaviours towards living in ways that do not include acts socially defined as crimes. Working in participatory ways meant some fundamental rethinking about what we were even trying to know. As we worked together to identify the important elements of Learning Together, our focus moved from trying to understand desistance from crime, towards trying to understand how we all reach our potential. Within this, each individual's experiences were important, but not because of a single particular embodiment or experience of marginalisation, but rather because each person involved was an individual site of expertise. If 'we' wanted to understand 'us' and what was happening to each of us within the process of Learning Together, we needed to understand our commonalities as well as our differences.

PAR also provided a methodological approach that felt more consistent for all of us with the theoretical framework that underpinned Learning Together - researching 'with' rather than 'on', which is important to both desistance and transformative learning and engendering an individual critical awareness through transparency, humility and honesty in a 'not knowingness'. Creating opportunities to speak and listen to each other in varied and creative 
ways, beyond traditional 'academic' approaches, made space for different voices and skills to be heard and celebrated that pushed our collective thinking in new ways. We were still trying to find ways to measure individual, institutional and social change, but the very exercise had become a manifestation and a furthering of community building, a partial embodiment of the change we wanted to see. Rather than our students feeling like something that was being shaped and studied, we all began to feel part of something bigger that we could shape together. As an 'us' we had potential. The locus of our study had somehow shifted, through the process of enquiry, from an 'I' to a 'we' - understanding that in so many ways our pasts and futures are inextricably bound up together.

Moving towards 'us' implied a move away from individualised notions of responsibility for past failures and future successes, within which much of our current criminal justice and higher education institutional realities and rewards are grounded. In place of scholarly detachment and distance, we found that PAR dragged us into reciprocal relationships of solidarity, towards what our colleague Max Harris (2017) has called 'a politics of love' - a politics grounded in everyday values that can be lived out in the ways we do research as well as what we hope to do with the findings. It felt like a move from what Martin Luther King (1963) describes as 'mere existence' that is 'too unconcerned to love and too passionate to hate, too detached to be selfish and too lifeless to be unselfish, too indifferent to experience joy and too cold to express sorrow', towards developing 'passionate attachments' - expanding our 'circles of concern' (Nussbaum, 2013). This new politics coproduced knowledge, empowered students with diverse skills and experiences, opened up for fresh examination our roles and identities as researchers and challenged us all to think more critically about what we aspire to achieve with our talents and futures. Through research we were not just learning how to recognise and measures movements towards potential, we were reshaping and redefining potentials together in the process.

The benefits for our research, and for all of us participating in it in our different roles, go some way towards addressing Anne's concerns. Together we challenged our perspectives on power, strengths and vulnerabilities - where and in whom they lie. We learned how to share and hold different kinds of power. We leant into the co-imagined purposes of research and began to care more about the processes and the understandings generated than the outputs. We reimagined ourselves and each other as researchers and participants, dislocating presumptions of privilege and vulnerabilities, appreciating and learning to accept and celebrate differences and growing an increasing awareness of our responsibilities for ourselves and to each other. The politics of love that grew through our collaborations shaped us all as individuals and professionals. We began by wanting to become change makers, but found we became changed.

\section{Disruptions, difficulties and discomforts of PAR - Sarah, Angela, Haydn and Patrick's experiences}

The egalitarian ethos underpinning participatory approaches to research is attractive precisely because of its promise to unseat some of the power dynamics inherent in being either 'researcher' or 'researched'. But power dynamics do not change without discomfort. Our experiences, and that of our collaborators, were complex and, in this penultimate section, we attempt to describe some of these complexities to think about the lessons learnt, and to try to extrapolate what we found to be the benefits of PAR notwithstanding these challenges.

Our first discomfort relates to Anne's concerns about being a data point. One of the promises of PAR is that, through processes of co-constructing knowledge, participants become actors in the planning, implementation and dissemination of research and, through this repositioning, the experience of participation is less objectifying and more empowering. This was not Sarah's experience. As described above, one of the participatory methods we used involved focus groups in which we shared experiences of learning and growth. Having anonymised what was shared, we all worked together to identify themes that ran through these experiences. Sarah took part in this exercise, but later explained to us in interview that she felt horrified that her own anonymised experiences became the topic of group discussion.

Far from removing the ethical complexities of feeling objectified like a data point, for Sarah this form of participatory analysis intensified as the site of objectification moved from the ostensibly trained and 'professional' researcher, to a group of her peers publicly analysing her experiences. Her feedback helpfully highlighted the need for clarity about precisely what participants are opting into when they agree to participate - what will constitute 'data', who will work with it and to what ends? This is perhaps uniquely difficult to define if co-production is really at the heart of the process, and perhaps also very difficult to resist if you find them objectifying even though you formed part of the group that agreed these processes. Might it feel uniquely disempowering to feel like the author of your own objectification? We wonder whether some forms of participation may just cloud the lines of responsibility for ethical practice through diffusion and confusion about power and expertise, and make it harder for individuals who feel uncomfortable with these processes to opt out.

Angela's concerns develop these points. Angela was a member of the Learning Together community at our second prison partnership from the University of Cambridge. Within this phase of the project, participants were engaging with, and seeking to develop, research tools that had grown out of the first phase of the research at a different prison. Angela raised two, interconnected, complexities. She recognised the benefits of new knowledge building on, and growing from, 
existing knowledge, but queried whether 'true' co-production was inherently context specific. If so, her concern was that a 'true' participatory approach is incapable of replicability or broader application. The same methods, in a different context, might come up with different lines of inquiry, different ways of inquiring and different methods of dissemination aimed towards distinct goals for change as defined by that particular participatory community. Building from this, Angela's second query was whether PAR would always need to be context (location/time) specific to involve authentic coproduction. For Angela, there had been rather too much 'co' in co-production, which she found to be overbearing, extractive and distracting. She wondered about the value of that distraction in the context of having 'imposed' a research framework and pre-established agenda from the first partnership site. She questioned its relevance for their new and different learning community and queried whether meaningful participation might require some methodological training.

It is of course possible to have different kinds and levels of participatory approaches Escober (2018) - but Angela's concerns seem to develop Sarah's disquiets about power, to ask questions about the purpose and process of research. Angela's reflections speak to the potential value of expertise guiding the framing of questions, the methods that might help us to inquire into these questions, and the outcomes we might pragmatically be able to aim for with findings generated through our choice of questions and methods. Her points outline that Anne's concerns about the purposes of research and what it achieves may not be satisfactorily answered by a participatory approach that is not adequately facilitated or where the participants are not effectively trained in the skills necessary to make the decisions with which they are tasked. Pragmatically, if participants are concerned to describe transformative outcomes and process, and are aiming to shape criminal justice policy, they could study individual and institutional experiences and changes in one course and perhaps effect some local changes. If their ambitions are to shape national policy, they may need multi-site and longitudinal evidence. If a new PAR project is developed with the participants in each new site, the terms and methods may be distinct and therefore the desired knowledge and dissemination and impact may be impossible.

McIntyre's (2008) introduction to PAR she outlines how the participants in her studies 'engaged in collaborative processes aimed at improving and understanding their worlds in order to change them' and how, through participation, they 'took action to improve their conditions . . . and gain a better understanding of the external circumstances that structure their lives' (p. ix). Our experiences of PAR point to more complex experiences of participation. Far from empowering Haydn and Patrick to 'improve their conditions', their experiences of co-producing knowledge, and the understandings this generated of 'the external circumstances that structure their lives', produced new senses of disempowerment, pain and hopelessness.
Haydn participated in our song writing workshops to explore his experiences of learning and growth. He told us that the experience was empowering; it was a new space with enlivening interactions and less hierarchical and risk-oriented power dynamics to those he was accustomed to within the prison setting. But the workshops came to an end. Participatory projects can helpfully destabilise power hierarchies, critically exposing their assumptions and contours, but for Haydn, the euphoric empowerment of collaboration withered after each session when he returned to the wing:

You're achieving, or at least you're feeling like you're achieving, a common goal of some description. You feel like, 'Yeah!', and then you have to remind yourself of the boundaries. You have to go, 'Look, there are people who come into prison . . 'YYou want to say, 'Look, I think you people are great. I'd love to meet . . ' And it does hurt you, because I'm [out] here and I can't go . . . I can't go home with these people. I can't be friends with them. It is sad, because they bring quite a refreshing experience to prison, and it's a shame you can't take that with you [back to the wing].

Haydn described how the acceptance and empowerment he felt while involved in the research through PAR - a sense things could change and he could be part of this - crumbled in the face of his everyday realities in prison, and the weight of his offending history. These concerns were not isolated to participants resident in prison. Through collaborative working, Patrick described changes in how he viewed and experienced himself and others. These changes co-emerged with new realisations about the power of social structures, some of which prompted feelings of sadness, impotence and hopelessness:

I wasn't expecting to be welcome to be honest . . . I don't know if it was the same with everyone else, but at least in my group, it was love really. It was as if everyone really loved each other . . . and it was quite painful really coming away from the prison and then thinking about them going back to their cells . . . I'd come away feeling quite sad really that it wasn't carrying on, because I just wanted to keep going. I wanted to be at the same place so that they didn't have to go back to their cells. Yes, it just made me feel quite upset really, a lot of the time.

Working collaboratively, through PAR, can shape participants' practical and emotional understandings of people who are differently situated. This can bring a new and transformative lens to one's own life with transformative effect but, just as with Haydn, for Patrick, this implied feeling the absence of his new 'neighbours' in his everyday existence. It brought his own life into focus, and far from empowering him, his experiences made him realise the limits of his own agency in the face of exclusive and excluding inequitable social institutions and structures.

Through Haydn and Patrick's experiences, we see how individual empowerment, in the context of oppressive daily realities, can risk making the weight of deprivations and 
excluding or apparently disempowering life circumstances less bearable. For us, Haydn and Patrick's stories bring to life some of the hidden, and perhaps unintended, potential consequences of creating temporary 'spaces' in which power and community are reimagined and practised in ways that are at odds with other prevailing institutional or societal norms. Literature on PAR talks less about hopelessness and pain than it does about empowerment and transformation, and yet in our collective experiences, hopelessness and pain, and empowerment and transformation appear inherently bound together. Our argument is not that these harms are any less present in different methodological approaches, but perhaps that they are better hidden. We wonder about the ethical and emotional consequences of this, and the extent of our obligations to participants during and after research projects.

\section{Conclusion}

In their work on 'Affective Equality', Cantillon and Lynch (2017) begin:

The nurturing that produces love, care, and solidarity constitutes a discrete social system of affective relations. Affective relations are not social derivatives, subordinate to economic, political, or cultural relations in matters of social justice. Rather, they are productive human relations that literally make people up (or damage them) mentally, emotionally, physically, and socially. The affective worlds of love, care, and solidarity are therefore sites of political import for social justice that need to be examined in their own right while recognizing their interrelatedness with economic, political and cultural systems. (pp. 169-170)

Fraser (2010) posits equalisation of resources, respect and representation as the three 'conditions' of social justice (p. 365), but Cantillon and Lynch (2017) argue for a fourdimensional model of social justice that 'aligns relational equality with the equality of resources, respect, and representation' (p. 170).

One of the claims of PAR is that goes beyond the potential of 'conventional research paradigms [to] provide a framework for addressing the researcher-participant relationship, the co-developing of the research process, and the positioning of consciousness-raising and affecting change within the overall research experience' (McIntyre, 2008). In this article, we have raised some ethical concerns about participatory research, focussing particularly on questions of power, impact, purpose, and how all of these dynamics can shape the personhood of all involved in research. We have charted our own routes into PAR, outlining the potential we have experienced in PAR and some of the benefits that have flowed from this approach for us, for our participants and for our research. We have also described some discomforts with PAR and challenges, recognising that participation alone does not resolve some of the fundamental ethical concerns expressed by Anne, even if it might displace them.
While participatory approaches may bring about individual, social and cultural transformations in unique and compelling ways, we have highlighted some of the complexities and limitations to claims that PAR is necessarily any better than 'conventional research paradigms' - perhaps it is just different. But we want to conclude by suggesting these differences may still be uniquely important as a research method, because we have found that PAR has moved us as researchers and our participants into the 'affective world' in research.

Research and research methods are never neutral. Every act and every omission has a consequence. If Cantillon and Lynch are right, and affective dimensions of life are a core component of social justice, paying attention to the ways we constitute and reconstitute social relations in and through our methods becomes a prime ethical consideration, and perhaps should be the lens through which we mediate all other concerns. Participation mitigates the risks of abstraction and indifference. More than this, our experience has been that it can also generate affective relations that underpin the kind of equality oriented solidarity that unmasks systemic inequalities and deficiencies and gives rise to action. When you begin to see the world with new eyes and feel the world with a new heart, it becomes difficult to continue to inhabit the world through an old politics. For us, this has extended to our own career paths and a growing disenchantment with academia's hyper-individualistic, extractive and 'objective' tendencies, reflected especially in the contours of its reward and progression structures (we write more about these in a previous paper, Ludlow et al., 2019). When your community tells you that 'still being there' (Gareth, phase 1 of longitudinal study, 2018) is among the most significant transformative ingredients of what's happening, publishing a paper in an academic journal comes to feel like a much less pressing priority than other measures of success, such as creating a national network and securing buy in for the work to proliferate, investigating and challenging university hiring/studying policies for people with criminal convictions and creating partnerships and securing funding to respond to urgent need within our community people leaving prison who don't have enough to eat or can't access opportunities because they can't pay the bus fare.

These challenges are not unique to scholars using PAR, but our experience of collaborative methods has been that they have shifted our politics to make these questions simultaneously more pressing and less resolvable. PAR has made us feel like there is little ground to occupy between standing 'objectively' on the side-lines throwing stones, or jumping in the river and having stones thrown at you for too much 'activism' and too little engagement with conventional measures of success in academia. On some of the more difficult days, our response to Anne (and perhaps to others) might be to say 'fuck you and your fucking easy distinctions between social work and academic research'.

In the end participatory research doesn't resolve the many ethical and political questions about research - whose voice 'counts', what research is for, how we position ourselves and 
carry power and what happens when research comes to an end. However, for us, PAR has provided a framework for a process of inquiry that is imbued with love. This, we think, has helpfully shaped the nature and quality of our research; the questions in which we have a stake, how we go about answering those questions and our hopes for what research can and should achieve.

And did you get what you wanted from this life, even so?

I did.

And what did you want?

To call myself beloved, to feel myself beloved on the earth. (Raymond Carver, 1989 -cited by Cantillon and Lynch, 2017)

\section{Declaration of conflicting interests}

The author(s) declared no potential conflicts of interest with respect to the research, authorship and/or publication of this article.

\section{Funding}

The author(s) received no financial support for the research, authorship and/or publication of this article.

\section{ORCID iD}

Ruth Armstrong (iD) https://orcid.org/0000-0002-7958-2829

\section{Notes}

1. To learn more about Learning Together, please visit www. learningtogethernetwork.co.uk.

2. Across the Learning Together Network colleagues run partnerships with prisons and with students under probation supervision in the community.

3. https://tagonist.livejournal.com/199563.html.

4. Their work builds on that of Fraser (1997, 2005, 2008, 2010).

5. Learning Together has been supported by a wide range of funders, particularly the British Academy (from which we cite here the original research aspirations for the initiative), ESRC, the University of Cambridge, HMPPS, and philanthropic donations including from the Bromley Trust, Cairns Foundation, Fishmongers Company, Schroder Foundation, Rank Foundation and an individual donor who wishes to remain anonymous.

6. http://joelletaylor.co.uk.

7. https://www.voxliminis.co.uk.

8. https://chrisloades.webs.com.

9. Our thinking and practice has been inspired by much of Richard Sennett's writings, but especially by his blog on 'The Public Realm' https://www.richardsennett.com/site/senn/templates/general2.aspx?pageid $=16 \& \mathrm{cc}=\mathrm{gb}$

\section{References}

Allport GW (1954) The Nature of Prejudice. Boston, MA: AddisonWesley.
Armstrong R and Ludlow A (2016) Educational partnerships between universities and prisons: How learning together can be individually, socially and institutionally transformative. Prison Service Journal 225: 9-17.

Armstrong R and Maruna S (2016) Examining imprisonment through a social justice lens. In: Farrall S, Goldson B, Loader I, et al. (eds) Justice and Penal Reform: Reshaping the Penal Landscape. London: Routledge.

Armstrong R, Gelsthorpe L and Crewe B (2014) From paper ethics to real-world research: Supervising ethical reflexivity when taking risks in research with 'the risky'. In: Lumsden $\mathrm{K}$ and Winter A (eds) Reflexivity in Criminological Research. New York: Springer, pp. 207-219.

Bauman Z (2013 [2001]) Community: Seeking Safety in an Insecure World. New York: John Wiley \& Sons.

Behar R (2014 [1996]) The Vulnerable Observer: Anthropology That Breaks Your Heart. Boston, MA: Beacon Press.

Beyens K, Christiaens J, Claes B, et al. (2013) The Pains of Doing Criminological Research. Brussels: VUBPress.

Bosworth M and Hoyle C (2011) What is criminology? An introduction. In: Bosworth M and Hoyle C (eds) What is Criminology? Oxford: Oxford University Press, pp. 1-11.

Bottoms A (2008) The relationship between theory and empirical observations in criminology. In: King RD and Wincup E (eds) Doing Research on Crime and Justice. Oxford: Oxford University Press, pp. 75-116.

Bottoms A and Shapland J (2011) Steps towards desistance among male young adult recidivists. In: Farrall S, Hough M, Maruna S, et al. (eds) Escape Routes: Contemporary Perspectives on Life After Punishment. London: Routledge, pp. 43-80.

Cantillon S and Lynch K (2017) Affective equality: Love matters. Hypatia 32(1): 169-186.

Carlen P and Ayres França LA (2017) Alternative Criminologies. London: Routledge.

Dirkx J, Mezirow J and Cranton P (2006) Musings and reflections on the meaning, context, and process of transformative learning: A dialogue between John M. Dirkx and Jack Mezirow. Journal of Transformative Education 4(2): 123-139.

Escobar O (2018) Participar, para qué? Nueva Revista de Política, Cultura y Arte 2: 35-42.

Farrall S and Calverley A (2006) Understating Desistance from Crime: Emerging Theoretical Directions in Resettlement and Rehabilitation. Maidenhead: Open University Press.

Fine M (2016) Participatory designs for critical literacies from under the covers. Literacy Research: Theory, Method, and Practice 65(1): 47-68.

Fine M (2017) Leaky privates: Resisting the neoliberal public university and mobilizing movements for public scholarship. In: Denzin NK and Giardina MD (eds) Qualitative Inquiry in Neoliberal Times. New York: Routledge, pp. 104-129.

Flyvbjerg B (2001) Making Social Science Matter: Why Social Inquiry Fails and How It Can Succeed Again. Cambridge: Cambridge University Press.

Fraser N (1997) After the family wage: A post-industrial thought experiment. In: Nancy F (ed.) Justice Interruptus: Critical Reflections on the 'Postsocialist' Condition. London: Routledge, pp. 41-66.

Fraser N (2005) Reframing justice in a globalizing world. New Left Review 36: 69-88. 
Fraser N (2008) Scales of Justice: Reimagining Political Space in a Globalizing World. Cambridge, UK: Polity Press.

Fraser N (2010) Injustice at intersecting scales: On 'social exclusion'and the 'global poor'. European Journal of Social Theory 13(3): 363-371.

Freire P (1973) Education for Critical Consciousness. London: Bloomsbury Publishing.

Gelsthorpe L (2007) The Jack-Roller: Telling a story? Theoretical Criminology 11(4): 515-542.

Harris M (2017) The New Zealand Project. Wellington, New Zealand: Bridget Williams Books.

Hirschfield PJ and Piquero AR (2010) Normalization and legitimation: Modeling stigmatizing attitudes toward ex-offenders. Criminology 48(1): 27-55.

Holland J (2007) Emotions and research. International Journal of Social Research Methodology 10(3): 195-209.

hooks B (1990) Yearning: Race, Gender and Cultural Politics. Boston, MA: Southend Press.

King ML (1963) Strength to Love. New York: Harper \& Row.

LeBel TP, Burnett R, Maruna S, et al. (2008) The 'chicken and egg' of subjective and social factors in desistance from crime. European Journal of Criminology 5(2): 131-159.

Liebling A (2015) Appreciative inquiry, generative theory, and the 'failed state prison'. In: Palacios WR (ed.) Qualitative Research in Criminology: Advances in Criminological Theory. New Brunswick, NJ: Transaction Publishers, pp. 251-269.

Liebling A and Arnold H (2004) Prisons and Their Moral Performance: A Study of Values, Quality, and Prison Life. Oxford: Oxford University Press.

Lincoln YS and Denzin NK (2003) Turning Points in Qualitative Research: Tying Knots in a Handkerchief. Walnut Creek, CA: AltaMira Press.

Ludlow A, Armstrong R and Bartels L (2019) Learning together: Localism, collaboration and reflexivity in the development of prison and university learning communities. Journal of Prison Education and Reentry 6(1): 25-45.

McIntyre A (2008) Participatory Action Research (Qualitative Research Methods Series 52). Los Angeles, CA: SAGE.

Maiese M (2017) Transformative learning, enactivism, and affectivity. Studies in Philosophy and Education 36(2): 197-216.

Mezirow J (2000) Learning as Transformation: Critical Perspectives on a Theory in Progress (The Jossey-Bass Higher and Adult Education Series). San Francisco, CA: Jossey-Bass.

Miller T (2012) Reconfiguring research relationships: Regulation, new technologies and doing ethical research. In: Crabtree B and Miller WL (eds) Ethics in Qualitative Research (2nd edn). London: SAGE, pp. 29-43.

Nussbaum MC (2013) Political Emotions. Cambridge, MA: Harvard University Press.
Ramazanoglu C and Holland J (2002) Feminist Methodology: Challenges and Choices. London: SAGE.

Sayer A (2011) Why Things Matter to People: Social Science, Values and Ethical Life. Cambridge: Cambridge University Press.

Seligman AB (2008) Living together differently. Cardozo Law Review 30: 2881-2896.

Sennett R (2012) Together: The Rituals, Pleasures and Politics of Cooperation. New Haven, CT: Yale University Press.

Sharpe G (2016) Sociological stalking? Methods, ethics and power in longitudinal criminological research. Criminology \& Criminal Justice 17(3): 233-247.

Tyler I (2008) 'Chav mum, chav scum': Class disgust in contemporary Britain. Feminist Media Studies 8(1): 17-34.

Valentine G (2008) Living with difference: Reflections on geographies of encounter. Progress in Human Geography 32(3): 323-337.

Weare K (2003) Developing the Emotionally Literate School. London: SAGE.

Weaver B (2015) Offending and Desistance: The Importance of Social Relations. London: Routledge.

Wikström P-OH and Treiber K (2007) The role of self-control in crime causation: Beyond Gottfredson and Hirschi's general theory of crime. European Journal of Criminology 4(2): 237-264.

Wooldredge J and Smith P (2018) The Oxford Handbook of Prisons and Imprisonment. Oxford: Oxford University Press.

\section{Author biographies}

Ruth Armstrong founded and directs Learning Together at the University of Cambridge. Learning Together is an international action research initiative that builds communities of learning designed to be inclusive of people under criminal justice supervision, whether in prison or in the community. She is a Senior Research Associate and Lecturer in Criminology at the University of Cambridge, with expertise in prisons, life after prison, and the process of building a crime free life. She has published widely on topics relating to these matters, with a focus on research that prioritises the experiences and issues that matter to people participating in research.

Amy Ludlow founded and directs Learning Together at the University of Cambridge, Learning Together is an international action research initiative that builds communities of learning designed to be inclusive of people under criminal justice supervision, whether in prison or in the community. She is a Senior Research Associate and Senior Lecturer in Law at the University of Cambridge, with expertise in employment law, public procurement, particularly specialising in areas related to prisons and criminal justice more broadly with a focus on socio-legal methodology. 